\title{
Hydrogen bonding in borcarite, an unusual borate-carbonate mineral
}

\author{
P. C. BURns* AND F. C. Hawthorne \\ Department of Geological Sciences, University of Manitoba, Winnipeg, Manitoba, Canada R3T 2N2
}

\begin{abstract}
The crystal structure, including hydrogen positions, of borcarite, $\mathrm{Ca}_{4} \mathrm{Mg}\left[\mathrm{B}_{4} \mathrm{O}_{6}(\mathrm{OH})_{6}\right]\left(\mathrm{CO}_{3}\right)_{2}$, monoclinic, $a=$ $17.840(4), b=8.380(2), c=4.445(1) \AA, \beta=102.04(3)^{\circ}, V=649.9(3) \AA^{3}$, space group $C 2 / m$, has been refined by full-matrix least-squares methods to $R=2.5 \%$ and $w R=3.0 \%$ for 1020 unique observed $[|F| \geqslant 5 \sigma(\mathrm{F})]$ reflections collected using Mo- $K \alpha \mathrm{X}$-radiation. The $\mathrm{H}$ positions were located on difference-Fourier maps and were refined using the 'soft' constraint that $\mathrm{O}-\mathrm{H}$ distances are $\sim 0.96 \AA$. The 4:4T FBB (fundamental building block) of the borcarite structure contains four $\mathrm{B} \phi_{4}$ tetrahedra $(\phi=$ unspecified ligand) which share corners to form a four-membered polyhedral ring. Borcarite is the only mineral known to contain this FBB. The FBBs do not polymerize, but each shares three anions with an $\mathrm{Mg} \phi_{6}$ octahedron on either side, forming rods of composition $\left[\mathrm{MgB}_{4} \mathrm{O}_{6}(\mathrm{OH})_{6}\right]^{4-}$ along the $c$-axis. The rigidity of these rods is enhanced by hydrogen bonding, and individual rods are connected through $\mathrm{Ca} \phi_{8}$ polyhedra, $\mathrm{C} \phi_{3}$ triangles and hydrogen bonds.
\end{abstract}

KEYworDs: borcarite, crystal structure, hydrogen bond, borate, Russia.

\section{Introduction}

BorCaRITE, $\mathrm{Ca}_{4} \mathrm{Mg}\left[\mathrm{B}_{4} \mathrm{O}_{6}(\mathrm{OH})_{6}\right]\left(\mathrm{CO}_{3}\right)_{2}$, is a rare borate-carbonate mineral from Siberia, where it occurs as dense masses and as veins in kotoite marble and in ludwigite-szaibelyite-magnetite rock (Pertzev et al., 1965). The crystal structure of borcarite was solved by Yamnova et al. (1976), but they did not report the $\mathrm{H}$-atom positions. We are currently studying the infrared spectra of borate minerals in the principal $\mathrm{OH}$-stretching region (i.e. Burns and Hawthome, 1994a). As a part of this work, we have refined the structure of borcarite including the $\mathrm{H}$ positions, and we report the results of the refincment here.

\section{Experimental}

Samples of borcarite from Yakutskaya ASSR, Russia, were obtained from the Canadian Museum of Nature

*Present address: Department of Earth Sciences, University of Cambridge, Downing Street, Cambridge CB2 3EQ, UK (samples 53411 and 53412). A small crystal fragment was mounted on a Nicolet $R 3 m$ automated four-circle diffractometer. Twenty-six reflections over the range $5^{\circ} \leqslant 2 \theta \leqslant 35^{\circ}$ were centred using graphite-

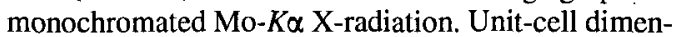
sions (Table 1) were derived from the setting angles of the twenty-six automatically aligned reflections by least-squares refinement. Data were collected using the $\theta / 2 \theta$ scan method with a $2.2^{\circ} 2 \theta$ scan-range and a variable scan-rate ranging from 4 to $29.3^{\circ} 2 \theta / \mathrm{min}$. A total of 1969 reflections was measured; the index ranges $0 \leqslant h \leqslant 25,-11 \leqslant k \leqslant 11,-6 \leqslant 1 \leqslant 6$ were covered and reflections forbidden by the Ccentring were omitted. Two standard reflections were measured every fifty reflections; no significant change in their intensities occurred during data collection. An empirical absorption correction based on 36 psi-scans for each of 10 reflections over the range $9^{\circ} \leqslant 2 \theta \leqslant 56^{\circ}$ was applied, reducing $R$ (azimuthal) from 2.11 to $1.23 \%$. The data were corrected for Lorentz, polarization and background effects; of the 1969 reflections measured, there were 1020 unique reflections $\left(R_{\mathrm{int}}=1.55 \%\right)$ classed as observed $[|F| \geqslant 5 \sigma(F)]$. 
TABLE 1. Miscellaneous information for borcarite

\begin{tabular}{llll}
\hline$a(\AA)$ & $17.840(4)$ & Crystal size $(\mathrm{mm})$ & $0.04 \times 0.15 \times 0.12$ \\
$b(\AA)$ & $8.380(2)$ & & \\
$c(\AA)$ & $4.445(1)$ & Total ref. & 1969 \\
$\beta\left({ }^{\circ}\right)$ & $102.04(3)$ & $\left|F_{0}\right| \geqslant 5 \sigma(F)$ & 1020 \\
$V\left(\AA^{3}\right)$ & $649.9(3)$ & $R_{\text {int }}$ & $1.55 \%$ \\
Space group & $C 2 / m$ & Final $R$ & \\
$F(000)$ & 548 & Final $w R$ & $2.5 \%$ \\
$D_{\text {calc }}$ & $2.790 \mathrm{~g}^{-\mathrm{cm}^{3}}$ & $3.0 \%$ \\
$\mu$ & $1.79 \mathrm{~mm}^{-}$ & \\
Unit cell contents $\left.2\left(\mathrm{Ca}_{4} \mathrm{Mg}^{3}\left[\mathrm{~B}_{4} \mathrm{O}_{6}(\mathrm{OH})_{6}\right]\left(\mathrm{CO}_{3}\right)_{2}\right)\right\}$ & \\
$R=\Sigma\left(\left|F_{\mathrm{o}}\right|-\left|F_{\mathrm{c}}\right|\right) / \Sigma\left|F_{0}\right|$ & \\
$w R=\left[\Sigma w\left(\left|F_{0}\right|-\mid F_{\mathrm{c}}\right)^{2} / \Sigma F_{0}^{2}\right]^{1 / 2}, w=1 / \sigma^{2}(F)$ & \\
\hline
\end{tabular}

\section{Structure refinement}

Scattering curves for neutral atoms, together with anomalous-dispersion corrections, were taken from Cromer and Mann (1968) and Cromer and Liberman (1970), respectively. The Siemens SHELXTL PLUS (PC version) system of programs was used throughout this study. The $R$ indices are of the form given in Table 1 and are expressed as percentages.

Refinement of the structure was done in the space group $C 2 / m$ using the atomic parameters of Yamnova et al. (1976) as the starting model. Refinement of the positional and isotropic-displacement parameters gave an $R$ index of $4.3 \%$. Conversion to an anisotropic-displacement model, together with refinement of all parameters, gave an $R$ index of $2.6 \%$. At this stage of the refinement, a differenceFourier map was calculated, and the positions of two $\mathrm{H}$ atoms were located. Subsequent cycles of refinement showed that the $\mathrm{H}$ positions were not realistic, as indicated by anomalously short $\mathrm{O}-\mathrm{H}$ bond lengths, a common feature of $\mathrm{H}$ positions refined using X-ray data. The 'soft' constraint that $\mathrm{O}-\mathrm{H}$ distances should be $\sim 0.96 \AA$ was imposed by adding extra weighted observational equations to the least-squares matrix. Only the $\mathrm{O}-\mathrm{H}$ distance is constrained, and each $\mathrm{H}$ position is free to seek its optimum position around the oxygen atom. Neutrondiffraction studies (e.g. Hamilton and Ibers, 1968) of structures containing hydrogen bonds have shown that donor-H bond lengths do vary somewhat with the $\mathrm{H}$-acceptor bond length. However, the donor-H bond lengths obtained via unconstrained refinement of $\mathrm{X}$-ray data normally fall well outside the range found using neutron data, and this makes the hydrogen bonding in the structure difficult to interpret. Neutron-diffraction studies of borate minerals are limited due to extreme absorption effects. Therefore, the most appropriate way to obtain hydrogen bonding information is via constrained refinement of X-ray data. We have found (Burns and Hawthorne, 1993a,b, 1994b,c,d) that this approach gives realistic hydrogen-bonding schemes for various borate minerals. Refinement of all parameters gave a final $R$ index of $2.5 \%$ and a $w R$ index of $3.0 \%$. A refinable weighting scheme of structure factors and a correction for isotropic extinction were tried, but did not improve the refinement results. Final positional and displacement parameters are given in Table 2, selected interatomic distances and angles in Table 3 , and a bond-valence analysis is given in Table 4. Observed and calculated structure factors have been deposited with the editor of Mineralogical Magazine and are available on request.

\section{Discussion}

Borate fundamental building block. There are two symmetrically distinct $B$ positions in the borcarite structure, and both are tetrahedrally coordinated by $(\mathrm{O}, \mathrm{OH})$. The borate fundamental building block (FBB) in this structure is a $\left[\mathrm{B}_{4} \mathrm{O}_{6}(\mathrm{OH})_{6}\right]^{6-}$ boron-oxygen ring (Fig. 1) made up of four $\mathrm{B} \phi_{4}$ tetrahedra. Each $\mathrm{B} \phi_{4}$ tetrahedron shares corners with two adjacent $\mathrm{B} \phi_{4}$ tetrahedra, forming a four-membered polyhedral ring, and the borate FBBs are isolated (i.e. are not polymerized) in the structure. According to the rules of Christ and Clark (1977), the shorthand notation for this FBB is $4: 4 \mathrm{~T}$, and borcarite is the only mineral that is known to contain this FBB.

The $\mathrm{B} 1 \mathrm{O}_{2}(\mathrm{OH})_{2}$ and $\mathrm{B}_{2} \mathrm{O}_{3}(\mathrm{OH})$ tetrahedra have $<\mathrm{B}-\mathrm{O}>$ distances of 1.483 and $1.484 \AA$, respectively, values which are within the range of $\left\langle{ }^{[4]} \mathrm{B}-\mathrm{O}\right\rangle$ observed in minerals. The $\mathrm{B} 1 \phi_{4}$ tetrahedron shows typical bond-length ranges (Table 3 ). However, the $\mathrm{B} 2 \phi_{4}$ tetrahedron is considerably more distorted than is usual for $\mathbf{B} \phi_{4}$ tetrahedra in minerals; there is one short B-O distance (1.397 $\AA$, see Table 3 ) and three 
TABle 2. Final atomic parameters for borcarite

\begin{tabular}{|c|c|c|c|c|c|c|c|c|c|c|}
\hline & $x$ & $y$ & $z$ & $* U_{\mathrm{eq}}$ & $* * U_{11}$ & $U_{22}$ & $U_{33}$ & $U_{12}$ & $U_{13}$ & $U_{23}$ \\
\hline $\mathrm{Ca}$ & $0.15543(2)$ & $0.23368(5)$ & $0.1548(1)$ & $90(1)$ & $81(2)$ & $77(2)$ & $109(2)$ & $-8(2)$ & $15(1)$ & $-12(2)$ \\
\hline $\mathrm{Mg}$ & 0 & 0 & 0 & $53(4)$ & $46(7)$ & $72(7)$ & $40(7)$ & 0 & $10(5)$ & 0 \\
\hline B1 & 0 & $0.2400(4)$ & $1 / 2$ & $130(8)$ & $124(13)$ & $125(14)$ & $139(13)$ & 0 & $23(10)$ & 0 \\
\hline B2 & $0.0948(2)$ & 0 & $0.6171(8)$ & $80(8)$ & $65(14)$ & $84(14)$ & $82(14)$ & 0 & $-5(11)$ & 0 \\
\hline C & $0.3048(2)$ & 0 & $0.2515(7)$ & $106(8)$ & $83(13)$ & $125(14)$ & $92(13)$ & 0 & $-24(10)$ & 0 \\
\hline 01 & $0.0994(1)$ & 0 & $0.3071(5)$ & $85(6)$ & $91(10)$ & $97(10)$ & $67(9)$ & 0 & $15(7)$ & 0 \\
\hline $\mathrm{O} 2$ & $0.05513(8)$ & $0.1427(2)$ & $0.7204(3)$ & $81(4)$ & $88(7)$ & $77(7)$ & $73(7)$ & $17(5)$ & $4(5)$ & $1(5)$ \\
\hline $\mathrm{OH} 3$ & $0.04149(9)$ & $0.3385(2)$ & $0.3095(3)$ & $97(4)$ & $105(7)$ & $90(7)$ & $100(7)$ & $-12(6)$ & $30(5)$ & $14(6)$ \\
\hline $\mathrm{O} 4$ & $0.2150(1)$ & $0.3654(2)$ & $0.6487(4)$ & $201(5)$ & $143(8)$ & $206(9)$ & $221(9)$ & $57(7)$ & $-36(7)$ & $-118(8)$ \\
\hline OH5 & $0.1743(1)$ & 0 & $0.8236(5)$ & $102(6)$ & $71(10)$ & $137(11)$ & $93(10)$ & 0 & $7(8)$ & 0 \\
\hline O6 & $0.3441(2)$ & 0 & $0.0398(6)$ & $176(7)$ & $246(13)$ & $155(12)$ & $156(12)$ & 0 & $105(10)$ & 0 \\
\hline H1 & $0.005(1)$ & $0.355(4)$ & $0.127(4)$ & +300 & & & & & & \\
\hline $\mathrm{H} 2$ & $0.212(2)$ & 0 & $0.698(9)$ & ${ }^{+} 300$ & & & & & & \\
\hline
\end{tabular}

${ }^{*} U_{\text {eq }}=U_{\text {eq }} \AA^{2} \times 10^{4}$

${ }^{* *} U_{\mathrm{ij}}=U_{\mathrm{ij}} \AA^{2} \times 10^{4}$

+ fixed during refinement

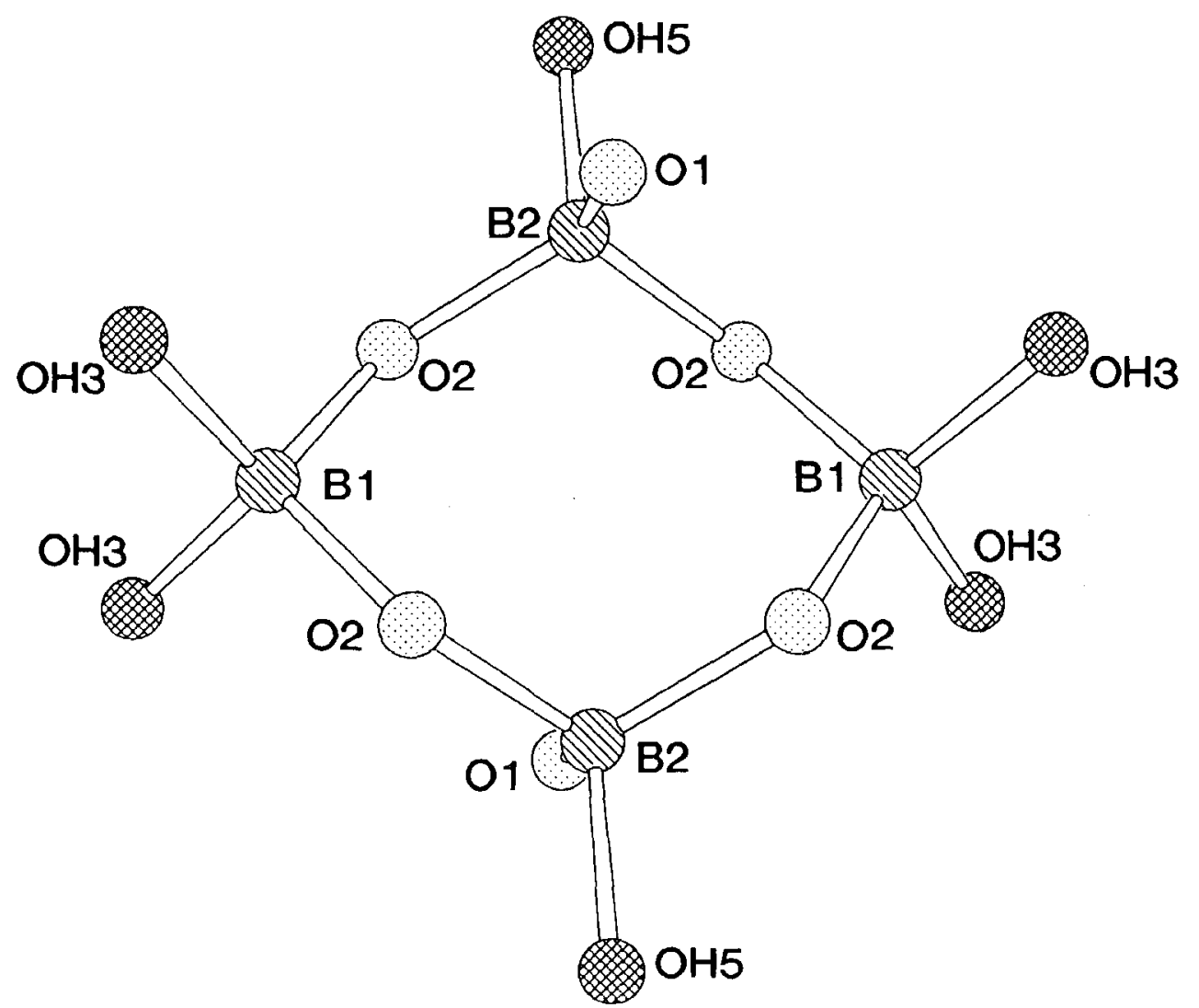

FIG. 1. The borate FBB in borcarite. $\mathrm{B}$ atoms are ruled with parallel lines, $\mathrm{OH}$ anions are cross-hatched, and $\mathrm{O}$ atoms are stippled. 
TABLE 3. Selected interatomic distances $(\AA)$ and angles $\left(^{\circ}\right)$ for borcarite

\begin{tabular}{|c|c|c|c|}
\hline $\mathrm{Ca}-\mathrm{O} 1$ & $2.361(2)$ & $\mathrm{B} 1-\mathrm{O} 2, \mathrm{f}$ & $1.480(2)$ \\
\hline $\mathrm{Ca}-\mathrm{OH} 3$ & $2.441(2)$ & $\mathrm{B} 1-\mathrm{OH} 3, \mathrm{f}$ & $1.486(3)$ \\
\hline $\mathrm{Ca}-\mathrm{O} 4$ & $2.489(2)$ & $\langle\mathrm{B} 1-\mathrm{O}\rangle$ & 1.483 \\
\hline $\mathrm{Ca}-\mathrm{O} 2 \mathrm{a}$ & $2.464(2)$ & & \\
\hline $\mathrm{Ca}-\mathrm{O} 4 \mathrm{a}$ & $2.899(2)$ & B2-O1 & $1.397(4)$ \\
\hline $\mathrm{Ca}-\mathrm{O} 4 \mathrm{~b}$ & $2.439(2)$ & $\mathrm{B} 2-\mathrm{O} 2, \mathrm{~h}$ & $1.509(3)$ \\
\hline $\mathrm{Ca}-\mathrm{OH} 5 \mathrm{a}$ & $2.514(2)$ & B2-OH5 & $1.520(4)$ \\
\hline $\mathrm{Ca}-\mathrm{O} 6 \mathrm{c}$ & $2.394(1)$ & $\langle\mathrm{B} 2-\mathrm{O}\rangle$ & 1.484 \\
\hline \multirow[t]{2}{*}{$\langle\mathrm{Ca}-\mathrm{O}\rangle$} & 2.500 & & \\
\hline & & $\mathrm{C}-\mathrm{O} 6$ & $1.285(3)$ \\
\hline $\mathrm{Mg}-01, \mathrm{~d}$ & $1.999(2) \times 2$ & $\mathrm{C}-\mathrm{O} 4 \mathrm{~b}, \mathrm{i}$ & $1.289(3)$ \\
\hline $\mathrm{Mg}-\mathrm{O} 2 \mathrm{a}, \mathrm{e}, \mathrm{f}, \mathrm{g}$ & $2.110(2) \times 4$ & $\langle\mathrm{C}-\mathrm{O}\rangle$ & 1.288 \\
\hline$\langle\mathrm{Mg}-\mathrm{O}\rangle$ & 2.073 & & \\
\hline
\end{tabular}

Hydrogen bonding

$\begin{array}{ll}\mathrm{H} 1-\mathrm{OH} 3 & 0.94(2) \\ \mathrm{OH} 3-\mathrm{OH} 3 \mathrm{j} & 2.839(3)\end{array}$

$\mathrm{H} 2-\mathrm{OH} 5$

$\mathrm{OH} 5-\mathrm{O} 4 \mathrm{~b}, \mathrm{i}$

$\mathrm{Mg} \phi_{6}$ octahedron

$\mathrm{O} 1, \mathrm{~d}-\mathrm{O} 2 \mathrm{a}, \mathrm{g}$ $\mathrm{O} 1, \mathrm{~d}-\mathrm{O} 2 \mathrm{e}, \mathrm{f}$

$\mathrm{O} 2 \mathrm{a}, \mathrm{e}-02 \mathrm{~g}, \mathrm{f}$

$\mathrm{O} 2 \mathrm{a}, \mathrm{e}-\mathrm{O} 2 \mathrm{f}, \mathrm{g}$

$<\mathrm{O}-\mathrm{O}>$

$\mathrm{B} 1 \phi_{4}$ tetrahedron

\begin{tabular}{|c|c|}
\hline $\mathrm{O} 2, \mathrm{f}-\mathrm{OH} 3$, & $2.430(2)$ \\
\hline $\mathrm{O} 2, \mathrm{f}-\mathrm{OH} 3, \mathrm{t}$ & $2.364(2)$ \\
\hline $\mathrm{O} 2-\mathrm{O} 2 \mathrm{f}$ & $2.470(3)$ \\
\hline $\mathrm{OH} 3-\mathrm{OH} 3 \mathrm{f}$ & 2.471(3) \\
\hline$\langle\mathrm{O}-\mathrm{O}\rangle$ & 2.421 \\
\hline
\end{tabular}

B $2 \phi_{4}$ tetrahedron

$\begin{array}{lll}\mathrm{O} 1-\mathrm{O} 2, \mathrm{~h} & 2.457(3) & \times 2 \\ \mathrm{O} 2, \mathrm{~h}-\mathrm{OH} 5 & 2.399(2) & \times 2 \\ \mathrm{O} 1-\mathrm{OH} 5 & 2.404(3) & \\ \mathrm{O} 2-\mathrm{O} 2 \mathrm{~h} & 2.391(3) & \\ <\mathrm{O}-\mathrm{O}\rangle & 2.418 & \end{array}$

$<\mathrm{O}-\mathrm{O}>$

$0.95(5)$

$3.363(3) \times 2$

$2.827(3) \quad \times 4$

$2.984(3) \times 4$

2.391(3) $\times 2$

$3.476(3) \times 2$

2.915

$\underset{\mathrm{OH} 3-\mathrm{H} 1-\mathrm{OH} 3 \mathrm{j}}{\mathrm{H} 1 \cdots \mathrm{OH}}$

$1.95(2)$

157(3)

$\mathrm{H} 2 \cdots \mathrm{O} 4 \mathrm{~b}, \mathrm{i}$
$0 \mathrm{H} 5-\mathrm{H} 2-\mathrm{O} 4 \mathrm{~b}, \mathrm{i}$

$2.49(2) \times 2$

$152(3) \times 2$

$\mathrm{C} \phi_{3}$ triangle

O6-O4b,i

$\mathrm{O} 4 \mathrm{~b}-\mathrm{O} 4 \mathrm{i}$

$<\mathrm{O}-\mathrm{O}>$

$$
\begin{aligned}
& \mathrm{O} 1, \mathrm{~d}-\mathrm{Mg}-\mathrm{O} 2 \mathrm{a}, \mathrm{g} \\
& \mathrm{O} 1, \mathrm{~d}-\mathrm{Mg}-\mathrm{O} 2 \mathrm{e}, \mathrm{f} \\
& \mathrm{O} 2 \mathrm{a}, \mathrm{e}-\mathrm{Mg}-\mathrm{O} 2 \mathrm{~g}, \mathrm{f} \\
& \mathrm{O} 2 \mathrm{a}, \mathrm{e}-\mathrm{Mg}-\mathrm{O} 2 \mathrm{f}, \mathrm{g} \\
& <\mathrm{O}-\mathrm{Mg}-\mathrm{O}>
\end{aligned}
$$
$\mathrm{O} 2$,f-B1-OH3,f
$\mathrm{O} 2, \mathrm{f}-\mathrm{Bl}-\mathrm{OH} 3, \mathrm{f}$
$\mathrm{O} 2-\mathrm{B} 1-\mathrm{O} 2 \mathrm{f}$
$\mathrm{OH} 3-\mathrm{B} 1-\mathrm{OH} 3 \mathrm{f}$
$<\mathrm{O}-\mathrm{B} 1-\mathrm{O}\rangle$

$\begin{array}{cc}86.9(1) & \times 4 \\ 69.0(1) & \times 4 \\ 93.1(1) & \times 2 \\ 111.0(1) & \times 2 \\ 90.0 & \end{array}$

$110.0(1) \quad \times 2$

$105.7(1) \quad \times 2$

113.1(3)

$112.5(3)$

109.5

\footnotetext{
$a=x, y, z-1 ; b=1 / 2-x, 1 / 2-y, 1-z ; c=1 / 2-x, 1 / 2-y,-z ; d=-x,-y,-z ; e=-x,-y, 1-z ; f=-x, y, 1-z ;$ $g=x,-y, z-1 ; h=x,-y, z ; i=1 / 2-x, y-1 / 2,1-z ; j=-x, y,-z$.
}

longer distances $(1.509$ to $1.520 \AA)$. The $\mathrm{B} 2 \phi_{4}$ tetrahedron shares two corners $(\mathrm{O} 2)$ with $\mathrm{Bl}_{4}$ tetrahedra (Fig. 1), and the $\mathrm{B} 2-\mathrm{O} 2$ distance is
$1.509 \AA$. The other two anions in the $B 2 \phi_{4}$ tetrahedron are non-bridging. In almost all hydrous borates, non-bridging oxygen atoms bond to a 
TABLE 4. Bond-valence* analysis (v.u.) for borcarite

\begin{tabular}{lcccccccc}
\hline & $\mathrm{Ca}$ & $\mathrm{Mg}$ & $\mathrm{B} 1$ & $\mathrm{~B} 2$ & $\mathrm{C}$ & $\mathrm{H} 1$ & $\mathrm{H} 2$ & $\Sigma$ \\
\hline $\mathrm{O} 1$ & 0.345 & $0.437 \downarrow^{\times 2}$ & & 0.932 & & & & 1.714 \\
$\mathrm{O} 2$ & 0.261 & $0.324 \downarrow^{\times 4}$ & $0.745 \downarrow^{\times 2}$ & $0.689 \downarrow^{\times 2}$ & & & & 2.019 \\
$\mathrm{OH} 3$ & 0.278 & & $0.733 \downarrow^{\times 2}$ & & & 0.80 & & 2.011 \\
& & & & & & 0.20 & & \\
O4 & 0.244 & & & & $1.314 \downarrow^{\times 2}$ & & $0.05 \downarrow^{\times 2}$ & 1.968 \\
& 0.279 & & & & & & & \\
OH5 & 0.081 & & & 0.669 & & & 0.90 & 1.797 \\
O6 & 0.228 & & & & 1.328 & & & 1.643 \\
$\Sigma$ & 0.315 & & & & & & & \\
\hline
\end{tabular}

* Bond-valence parameters from Brown and Altermatt (1985).

hydrogen atom, forming an hydroxyl group. This is the case for the $\mathrm{OH} 5$ anion of the $\mathrm{B} 2 \phi_{4}$ tetrahedron, and the $\mathrm{B} 2-\mathrm{OH} 5$ bond-length $(1.520 \AA)$ is typical. However, B2 also bonds to $\mathrm{O} 1$ which is a nonbridging oxygen atom that does not bond to an $\mathbf{H}$ atom. The $\mathrm{O} 1$ atom bonds to one $\mathrm{Ca}$ and one $\mathrm{Mg}$ atom as well, and if the B2-O1 distance was $\sim 1.48$ $\AA$, the bond-valence sum at B2 would be $\sim 1.55$ v.u., an unrealistically low total. Thus, the $\mathrm{O} 1$ atom moves closer to $\mathrm{B} 2$, increasing the bond-valence sum at the $\mathrm{O} 1$ position to 1.71 v.u. (Table 4).

$C \phi_{3}$ triangle. The structure contains one $\mathrm{C}$ position which is coordinated by three coplanar $\mathrm{O}$ atoms with a $<\mathrm{C}-\mathrm{O}>$ distance of $1.288 \AA$, a value typical for $\left(\mathrm{CO}_{3}\right)$ groups in minerals and inorganic structures. The carbonate triangle has two distinct bond lengths (Table 3) and is distorted, with bond angles of 118.90 and $122.2^{\circ}$, giving a $\left.<\mathrm{O}-\mathrm{C}-\mathrm{O}\right\rangle$ angle of $120.0^{\circ}$.

$\mathrm{Ca}_{8}$ and $\mathrm{Mg} \phi_{6}$ polyhedra. The borcarite structure has one unique $\mathrm{Ca}$ position which is coordinated by six $\mathrm{O}$ atoms and two hydroxyl groups. The $\mathrm{Ca}-\phi$ bond-lengths range from 2.361 to $2.899 \AA$, and the $\langle\mathrm{Ca}-\phi\rangle$ distance is $2.500 \AA$. The structure contains one symmetrically distinct $\mathrm{Mg}$ position which is octahedrally coordinated by six oxygen atoms. The octahedron is $(2+4)$ distorted, with four long $\mathrm{Mg}-\mathrm{O} 2$ bonds $(2.110 \AA$ ) and two short $\mathrm{Mg}-\mathrm{O} 1$ bonds $(1.999 \AA)$, giving a $<\mathrm{Mg}-\mathrm{O}\rangle$ distance of $2.073 \AA$. This distortion is due to the bond-valence requirements of the underbonded $\mathrm{Ol}$ position (see above, Table 4), which moves closer to $\mathrm{Mg}$ to increase the bond-valence sum at that position.

Structure connectivity. In the borcarite structure, the 4:4T borate FBBs are isolated from each other. The four-membered borate polyhedral ring provides three oxygen atoms that are in appropriate positions to be an octahedral face, and this is the point of attachment to the $\mathrm{Mg} \phi_{6}$ octahedron (Fig. 2a). Each FBB bonds to two $\mathrm{Mg} \phi_{6}$ octahedra, and each $\mathrm{Mg} \phi_{6}$ octahedron bonds to two FBBs, forming infinite rods of composition $\left[\mathrm{MgB}_{4} \mathrm{O}_{6}(\mathrm{OH})_{6}\right]^{4-}$ along the $c$-axis (Fig. $2 b$ ). These rods are $C$-centred and are crosslinked via $\mathrm{Ca}-\phi$ bonds in combination with the $\mathrm{C} \phi_{3}$ triangles (Fig. 3) and hydrogen bonds (see below).

Hydrogen bonding. The $\mathrm{H}$-atom positions obtained via constrained least-squares refinement of the $\mathrm{X}$-ray data are reasonable both in terms of donor and acceptor bond-lengths and angles (Table 3 ) and the bond-valence requirements of the donor and acceptor anions (Table 4).

There are two hydrogen positions in the structure of borcarite. The $\mathrm{OH} 3-\mathrm{H} 1 \ldots \mathrm{OH} 3$ bond has an acceptor distance of $1.95 \AA$, and is a fairly strong hydrogen bond. This bond bridges between adjacent borate FBBs within the same $\left[\mathrm{MgB}_{4} \mathrm{O}_{6}(\mathrm{OH})_{6}\right]^{4-}$ rod (Fig. 2a), thereby increasing the rigidity of this structural unit. The $\mathrm{OH} 3$ anion donates the hydrogen bond and accepts a hydrogen bond from $\mathrm{H} 1$ attached to a symmetrically equivalent $\mathrm{OH} 3$ position, forming $\mathrm{OH} 3-\mathrm{H} 1 \cdots \mathrm{OH} 3-\mathrm{H} 1$ rings (Fig. 2a). There are four hydrogen bonds between each adjacent borate FBB within the $\left[\mathrm{MgB}_{4} \mathrm{O}_{6}(\mathrm{OH})_{6}\right]^{4-}$ rod.

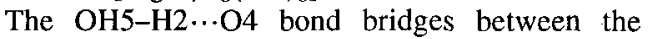
borate FBBs and adjacent $\mathrm{C}_{3}$ triangles (Fig. 3). The $\mathrm{H} 2$ position lies on a mirror plane in the space group $C 2 / m$, and there are two symmetrically equivalent $\mathrm{O} 4$ atoms that may act as acceptor anions. The $\mathrm{OH} 5-\mathrm{H} 2 \cdots \mathrm{O} 4$ bonds both have an acceptor distance of $2.49 \AA$, thus the bonds are rather weak. It is possible that this hydrogen bond is bifurcated to the two $\mathrm{O} 4$ anions, and a difference- 


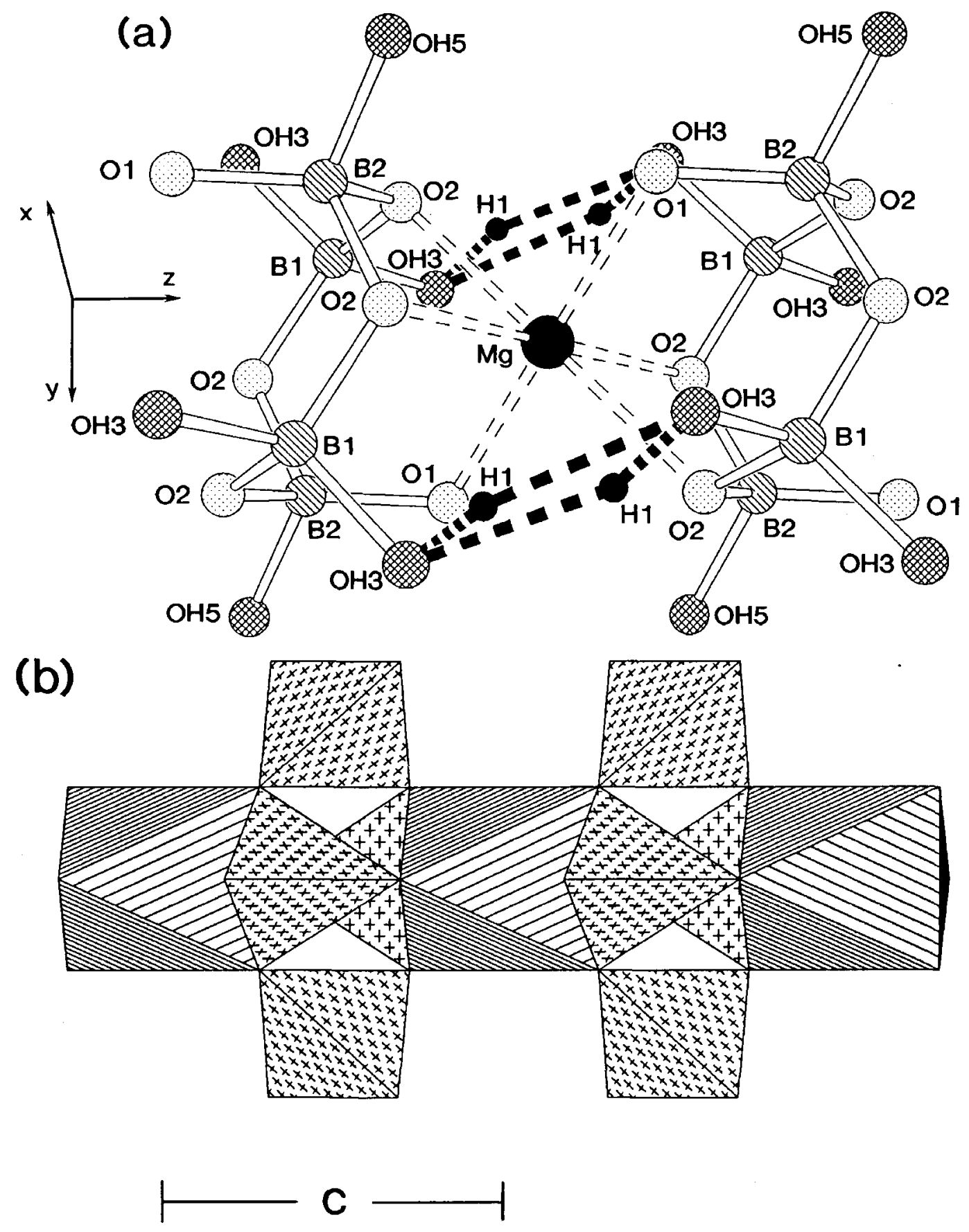

FIG. 2. The structure rod of composition $\left[\mathrm{MgB}_{4} \mathrm{O}_{6}(\mathrm{OH})_{6}\right]^{4-}:$ (a) the local environment of the borate FBB, B atoms are ruled with parallel lines, the $\mathrm{Mg}$ atom is a large solid circle, $\mathrm{OH}$ anions are cross-hatched, $\mathrm{O}$ atoms are stippled, $\mathrm{H}$ atoms are small solid circles; $\mathrm{O}-\mathrm{H}$ bonds are the short-dashed lines, $\mathrm{H} \cdots \mathrm{H}$ bonds are the long-dashed lines. $(b)$ the $\left[\mathrm{MgB}_{4} \mathrm{O}_{6}(\mathrm{OH})_{6}\right]^{4-}$ rod projected down the $a$-axis. $\mathrm{B} \phi_{4}$ tetrahedra are shaded with crosses and $\mathrm{Mg} \phi_{6}$ octahedra are ruled with parallel lines. 


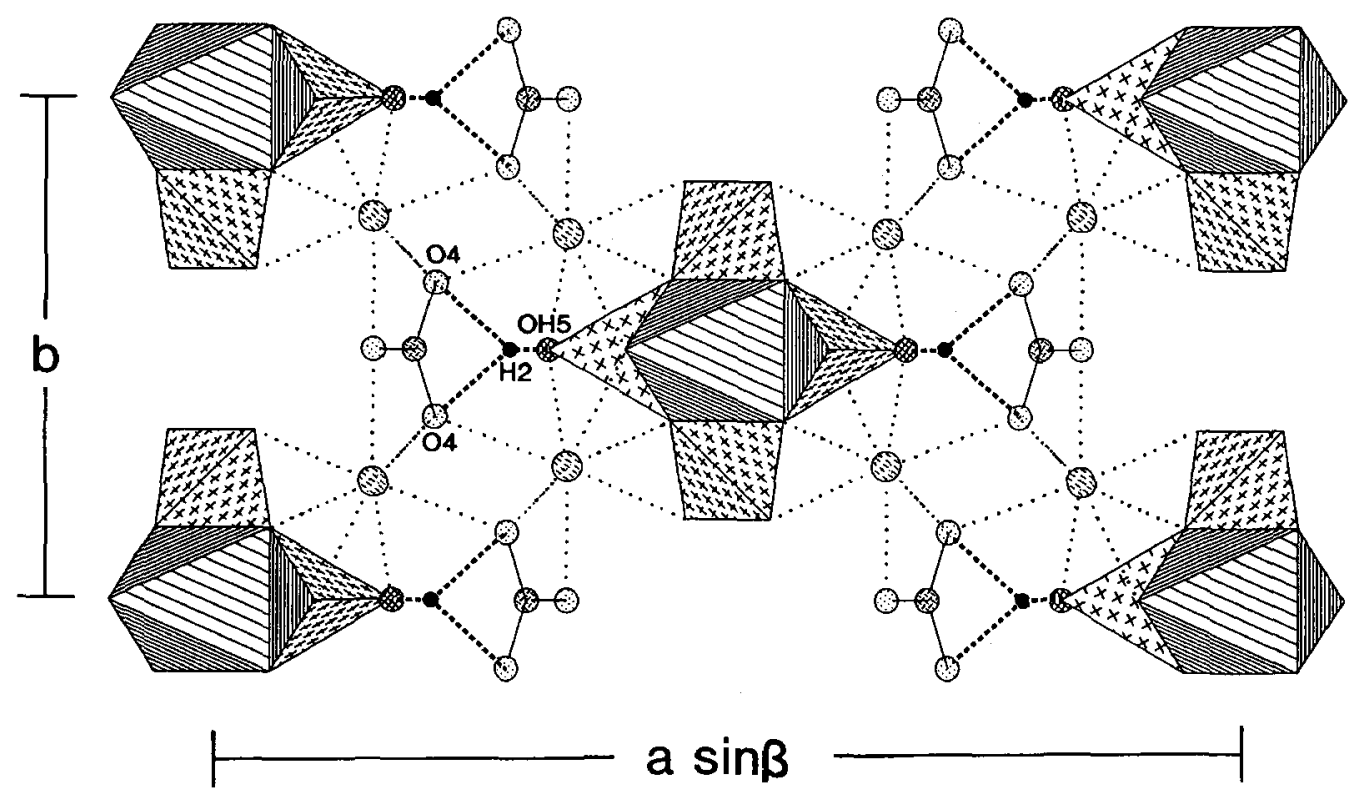

FIG. 3. The borcarite structure projected down the $c$-axis. $\mathbf{B} \phi_{4}$ tetrahedra are shaded with crosses, $\mathrm{Mg} \phi_{6}$ octahedra are ruled with parallel lines, oxygen atoms are stippled, $\mathrm{OH}$ anions are cross-hatched, $\mathrm{C}$ atoms are shaded with a herring-bone pattern, $\mathrm{Ca}$ atoms are ruled with broken parallel lines and $\mathrm{H}$ atoms are shown as small solid circles. $\mathrm{Ca}-\phi$ bonds are dotted, $\mathrm{C}-\phi$ are solid lines, $\mathrm{H}-\phi$ bonds are broken lines.

Fourier map calculated with the $\mathrm{H} 2$ atom removed from the structure model supports this hypothesis, as it shows that the electron density associated with the $\mathrm{H} 2$ position is somewhat anisotropic, with maximum displacements perpendicular to the mirror plane.

\section{Acknowledgements}

We are grateful to the Canadian Museum of Nature for providing the material used in this siudy. Financial support was provided by the Natural Sciences and Engineering Research Council of Canada in the form of Operating, Infrastructure and Major Equipment grants to $\mathrm{FCH}$.

\section{References}

Burns, P. C. and Hawthorne, F. C. (1993a) Hydrogen bonding in colemanite: an X-ray and structure energy study. Can. Mineral., 31, 297-304.

Burns, P. C. and Hawthorne, F. C. (1993b) Hydrogen bonding in meyerhofferite: an X-ray and structure energy study. Can. Mineral., 31, 305-12.

Burns, P. C. and Hawthorne, F. C. (1994a) Structure and hydrogen bonding in preobrazhenskite, a complex heteropolyhedral borate. Can. Mineral., 32, 387-96.

Burns, P. C. and Hawthorne, F. C. (1994b) Structure and hydrogen bonding in inderborite, a heteropolyhedral sheet structure. Can. Mineral., 32, 533-9.

Burns, P. C. and Hawthorne, F. C. (1994c) Kaliborite, an example of a crystallographically symmetrical hydrogen bond. Can. Mineral., 32, 885-94.

Burns, P. C. and Hawthorne, F. C. (1994d) Hydrogen bonding in tunellite. Can. Mineral., 32, 895-902.

Brown, I. D. and Altermatt, D. (1985) Bond-valence parameters obtained from a systematic analysis of the inorganic crystal structure database. Acta Crystallogr., B41, 244-7.

Christ, C. L. and Clark, J. R. (1977) A crystal-chemical classification of borate structures with emphasis on hydrated borates. Phys. Chem. Minerals, 2, 59-87.

Cromer, D. T. and Liberman, D. (1970) Relativistic calculation of anomalous scattering factors for Xrays. J. Chem. Phys., 53, 1891-8.

Cromer, D. T. and Mann, J. B. (1968) X-ray scattering factors computed from numerical Hartree Fock wave functions. Acta Crystallogr., A24, 321-4.

Hamilton, W. L. and Ibers, J. A. (1968) Hydrogen 
Bonding in Solids. W. A. Benjamin, Inc., New York. Pertzev, N. N., Ostravskaya, I. V. and Nikitina, I. B. (1965) The new mineral borcarite. Amer. Mineral., 50, 2097 (abstr.).

Yamnova, N. A., Simonov, M. A., Kazanskaya, E. V. [Manuscript received 1 June 1994:

and Belov, N. V. (1976) Refinement of the crystal revised 17 August 1994] structure of the $\mathrm{Ca}, \mathrm{Mg}$-carbonatoborate borcarite $\mathrm{Ca}_{4} \mathrm{Mg} / \mathrm{B}_{4} \mathrm{O}_{6}(\mathrm{OH})_{6} /\left(\mathrm{CO}_{3}\right)_{2}$. Sov. Phys. Dokl., 20, $799-801$. 